\title{
Understanding the mechanisms of glutamine action in critically ill patients
}

\author{
GISELE P. OLIVEIRA ${ }^{1}$, CRISTINA M. DIAS ${ }^{1}$, PAOLO PELOSI ${ }^{2}$ and PATRICIA R.M. ROCCO ${ }^{1}$ \\ ${ }^{1}$ Laboratório de Investigação Pulmonar, Instituto de Biofísica Carlos Chagas Filho \\ Universidade Federal do Rio de Janeiro, Centro de Ciências da Saúde, Av. Carlos Chagas Filho, s/n \\ Cidade Universitária, Ilha do Fundão, 21941-902 Rio de Janeiro, RJ, Brasil \\ ${ }^{2}$ Department of Ambient, Health and Safety, University of Insubria \\ Villa Toeplitz Via G.B. Vico, 4621100 , Varese, Italy \\ Manuscript received on May 22, 2009; accepted for publication on July 7, 2009
}

\begin{abstract}
Glutamine (Gln) is an important energy source and has been used as a supplementary energy substrate. Furthermore, Gln is an essential component for numerous metabolic functions, including acid-base homeostasis, gluconeogenesis, nitrogen transport and synthesis of proteins and nucleic acids. Therefore, glutamine plays a significant role in cell homeostasis and organ metabolism. This article aims to review the mechanisms of glutamine action during severe illnesses. In critically ill patients, the increase in mortality was associated with a decreased plasma Gln concentration. During catabolic stress, Gln consumption rate exceeds the supply, and both plasma and skeletal muscle pools of free Gln are severely reduced. The dose and route of Gln administration clearly influence its effectiveness: high-dose parenteral appears to be more beneficial than low-dose enteral administration. Experimental studies reported that Gln may protect cells, tissues, and whole organisms from stress and injury through the following mechanisms: attenuation of NF (nuclear factor) $-\kappa \mathrm{B}$ activation, a balance between pro- and anti-inflammatory cytokines, reduction in neutrophil accumulation, improvement in intestinal integrity and immune cell function, and enhanced of heat shock protein expression. In conclusion, high-doses of parenteral Gln (>0.50 g/ kg/day) demonstrate a greater potential to benefit in critically ill patients, although Gln pathophysiological mechanisms requires elucidation.
\end{abstract}

Key words: heat shock protein, apoptosis, cytokines, glutamine.

\section{INTRODUCTION}

Glutamine is an amino acid that has received considerable attention during the past 10 years. It has been shown to be beneficial for the metabolically stressed patient, especially the critically ill patients. During acute illnesses patients experience nutritional depletion that is correlated to low plasma and low mucosal glutamine concentrations (Oudemans-van Straaten et al. 2001). Such deficiencies are common among hospitalized patients and are associated with an increased risk of developing infectious complications, organ failure, and death (Roth et al. 1982, Planas et al. 1993, Oehler et al. 2002).

Correspondence to: Profa. Dra. Patricia Rieken Macedo Rocco E-mail: prmrocco@biof.ufrj.br
Glutamine has many essential metabolic functions in the organ. This amino acid is an energy substrate for most cells, especially for enterocytes and lymphocytes; it is also a precursor for nucleotide, glutamate, and, in particular, for glutathione synthesis, an important cellular antioxidant (Oba et al. 2004). It plays a central role in nitrogen transport within the body, and is the most important substrate for renal ammoniagenesis.

A number of clinical studies reveal a significant benefit of glutamine use on mortality (Griffiths et al. 1997, Goeters et al. 2002, Garrel et al. 2003, Andreasen et al. 2009), length of hospital stay (Ziegler et al. 2005, Zheng et al. 2006, 2007), and infectious morbidity (Wischmyer et al. 2001, Déchelotte et al. 2006, Tang et al. 
2007) in critical illnesses. Patients receiving high-dose parenteral glutamine presented the highest beneficial effects (Déchelotte et al. 2006, Tang et al. 2007).

Experimental studies in the current literature indicate that glutamine use may prevent the occurrence of lung injury, tissue metabolic dysfunction, and reduce mortality after injury (Doruk et al. 2005, Déchelotte et al. 2006, Morrison et al. 2006, Peng et al. 2006, Tang et al. 2007). The present review will focus on the effects of glutamine during critical illnesses.

\section{METABOLISM AND CATABOLISM OF GLUTAMINE IN NORMAL CONDITIONS}

Glutamine is the most abundant free amino acid in the body and commonly known as a nonessential amino acid due to the ability of most cells to produce it (Darmaun et al. 1986, Boza et al. 2000, Labow et al. 2001, Yeh et al. 2005). Glutamine is present in the plasma at levels around $0.6 \mathrm{mM}$ and in the intracellular space at levels around 2 and $20 \mathrm{mM}$ (Darmaun et al. 1986). It also serves as a metabolic intermediate, contributing carbon and nitrogen for the synthesis of other amino acids, nucleic acids, fatty acids, and proteins (Newsholme et al. 1986, Boza et al. 2000). Glutamine through glutamate is a glutathione precursor, a tripeptide consisting of glutamate, glycine, and cysteine, with intracellular antioxidant capacity (Oba et al. 2004). Thus, its functions within the cell are generally separated into four categories: 1) its role in nitrogen transport; 2) its importance in maintaining the cellular redox state; 3 ) its position as a metabolic intermediate; and 4) its role as an energy source. Although some tissues use glutamine for one pathway more than others, glutamine metabolism occurs in all cells (Newsholme et al. 1986).

Glutamine is synthesized by the cytosolic glutamine synthetase (GS) in many tissues, but degraded by mitochondrial glutaminase (GA) and utilized in high amounts by other tissues that do not synthesize it (Labow et al. 1998, 2001, Karinch et al. 2001). Thus, glutamine metabolism is controlled by glutamine synthetase and glutaminase (Labow et al. 1998, 2001) (Fig. 1) as follow:

$$
\begin{gathered}
\text { Glutamate }+\mathrm{NH}_{4}^{+}+\mathrm{ATP} \stackrel{\substack{\text { glutamine } \\
\text { synthetase }}}{\longrightarrow} \text { Glutamine }+\mathrm{ADP}+\mathrm{Pi}+\mathrm{H}^{+} \\
\text {Glutamine }+\mathrm{H}_{2} \mathrm{O} \stackrel{\text { glutaminase }}{\longrightarrow} \text { Glutamate }+\mathrm{NH}_{4}^{+}
\end{gathered}
$$

Glutamine catabolism is initiated by the removal of an amine group to form glutamate (Oba et al. 2004). This can occur through a number of cytosolic transaminase enzymes that use the $\gamma$-amino nitrogen of glutamine in a variety of metabolic synthesis. However, the rate at which these reactions utilize Gln depends ultimately upon the metabolic demand for the reaction products and is, therefore, not appropriate for the control of glutamine homeostasis (Labow et al. 2001). The mitochondrial enzyme glutaminase catalyzes the hydrolysis of the $\gamma$-amino group of Gln to form glutamate and ammonia (Labow et al. 2001, Oba et al. 2004). Ammonia can be used to form carbamoyl phosphate or can diffuse from the mitochondria and the cell itself. Furthermore, glutamate can form $\alpha$-ketoglutarate and, thus, enter into the citric acid cycle (Oba et al. 2004). Therefore, the catabolism of glutamine through glutaminase can be increased without the production of excessive amounts of specific metabolites (Fig. 1).

The synthesis of glutamine from glutamate is mediated by the enzyme glutamine synthetase. Thus, the regulated expression of this enzyme plays a key role in an organ's overall glutamine production rate. In contrast to the many enzymes that utilize glutamine as a substrate, only glutamine synthetase is responsible for de novo synthesis of glutamine. In this line, glutamine synthetase catalyses the formation of Gln from glutamate and ammonia in the cytoplasm (Labow et al. 1999, 2001) (Fig. 1). Because both of these substrates are relatively abundant, the rate of glutamine formation is highly dependent upon the activity of glutamine synthetase (Labow et al. 2001).

\section{METABOLISM AND CATABOLISM OF GLUTAMINE DURING CRITICAL ILLNESS}

The expression of glutamine synthetase in mammalian systems is regulated mainly via two mechanisms: a) increased transcription in response to hormone action (Abcouwer et al. 1995), and b) regulation of protein stability in response to glutamine concentration (Labow et al. 1998). During physiologic stress, as sepsis, a rapid increase in plasma concentrations of cytokines and several classes of hormones, such as glucocorticoids, occurs. Glucocorticoids are vital multi-faceted hormones with recognized effects on carbohydrate, protein and lipid 




Fig. 1 - Metabolism and anabolism of glutamine (Gln). Glutamine is synthesized by the action of glutamine synthetase (GS) and degraded by mitochondrial glutaminase (GA). Glutamine can be synthesized by most tissues in glutamate and ammonia. Ammonia can be used to form carbamoyl phosphate. Glutamate can form $\alpha$-ketoglutarate, glucose in the liver and kidneys, gluthatione in most of cells, and Gamma-aminobutyric acid (GABA) in neurons.

metabolism, and they are part of the acute stress response (Mezzarobba et al. 2003). They are considered the primary mediators of glutamine synthetase expression during stress, and act on the lung and skeletal muscle in a rapid and direct glucocorticoid receptor-mediated manner (Abcouwer et al. 1995). The transcriptional response of the rat glutamine synthetase gene to glucocorticoid has been characterized and shown to be attributable to two genetic regions. Each of these regions gives large glucocorticoid induction of transcription to the glutamine synthetase promoter, as well as heterologous promoter in a glucocorticoid-dependent fashion (Abcouwer et al. 1995).

Despite a large transcriptional response, glutamine synthetase protein levels do not always increase with GS mRNA levels, which suggests that the post-transcriptional control mechanism also regulates glutamine synthetase expression (Labow et al. 1998, 1999, 2001). Studies demonstrated that the presence of glutamine in the medium regulates glutamine synthetase expression via a post-transcriptional mechanism, where the rate of glutamine synthetase protein degradation is diminished and its activity is augmented in the presence of low glutamine concentration (Labow et al. 1998).

Although the skeletal muscle is the main source of Gln in normal conditions, skeletal muscles and lungs work together to maintain the circulating glutamine pool during critical illnesses (Buttrose et al. 1987, Labow et al. 2001).

The concentration of glutamine, in the skeletal muscle tissue, affects glutamine synthetase expression differently during acute stress compared with chronic stress and/or caloric deprivation. During acute stress, glucocorticoids and glutamine depletion increase muscle GS mRNA levels rapidly, while glutamine synthetase protein levels are limited (Labow et al. 1999). During a chronic stress, Gln may directly impact glutamine synthetase gene expression or potentates the effects of another mediator, such as glucocorticoids (Labow et al. 1999). Unlike in skeletal muscles, glutamine depletion 
increases glutamine synthetase protein stability in the lung, but without significant augment in GS mRNA (Elgadi et al. 1998). The combined effects of Gln depletion and glucocorticoids hormones can act synergistically to increase glutamine synthetase protein expression, allowing the lung to adjust GS activity to meet actual Gln demand (Labow et al. 1998).

\section{GLUTAMINE AND THE EXPRESSION OF HEAT SHOCK PROTEINS}

Glutamine's beneficial effects on critical illnesses may result from enhanced heat shock proteins (HSP) expression (Singleton et al. 2005b, Morrison et al. 2006) expressed by leucocytes (Oehler et al. 2002), monocytes (Eliasen et al. 2006), and granulocytes (Ganter et al. 2006). The heat shock proteins are a group of proteins essential to cellular survival under stressful conditions. These are a family of highly conserved proteins belonging to multigene families ranging in molecular size from 10 to $105 \mathrm{kDa}$ - different weights are used for identification -, and found in all major cellular compartments (Fleshner et al. 2004, Ganter et al. 2006).

The stress-inducible HSP70 and HSP72 are inducible forms of the stress protein, which may confer cellular protection (Oehler et al. 2001). Treatment of sepsisinduced acute lung injury with an adenovirus overexpressing HSP72 limits nuclear factor $(\mathrm{NF}) \kappa \mathrm{B}$ (a crucial transcription factor regulating the expression of many pro-inflammatory cytokines and immunoregulatory molecules) activation and prevents lung injury (Weiss et al. 2007). There is evidence that Gln can enhance HSP70 and 72 expression in lung macrophages and epithelial cells (Singleton et al. 2005c) leading to marked protection against sepsis-induced injury (Singleton et al. 2005b, Singleton and Wischmeyer 2007). The cellular functions of intracellular HSP70 and HSP72 are responsible for limiting protein aggregation, facilitating protein refolding, and chaperoning proteins. These cellular functions serve to improve cell survival in the face of a broad array of cellular stressors (Oehler et al. 2001).

It has been recognized that HSP72 is also found in extracellular space (eHSP72) where it exerts immunomodulatory function on innate and acquired immunity (Wright et al. 2000). In fact, during the early phase of ALI, there was an activation of the stress protein re- sponse (SPR) and a release of HSP72 into the alveolar spaces. HSP72 may serve as a marker of stress protein response activation in the distal air spaces of ALI patients, while SPR activation may protect the alveolar epithelium against oxidative stress (Ganter et al. 2006). Initially, studies reported that eHSP72 was only released as a result of necrotic/lytic cell death, but it is now recognized that elevated eHSP72 may be found in the absence of necrosis (Ganter et al. 2006). In this context, Ganter and colleagues (2006) showed a preserved alveolar fluid clearance and high levels of eHSP72 in pulmonary edema fluid of ALI patients, suggesting that the high level of eHSP72 is not related to cell injury in distal air spaces. It seems that, under physical or psychological acute stress, eHSP72 may exacerbate inflammatory process (Asea et al. 2000) or stimulate the release of endogenous eHSP72 into the blood via an a1adrenergic receptor-mediated mechanism facilitating the innate immunity (Campisi et al. 2003).

Glutamine starvation reduces the HSP70 expression since it decreases HSP70 mRNA expression (Eliasen et al. 2006). As plasma glutamine depletion occurs during systemic inflammation, the impaired HSP70 expression under these conditions is likely to have deleterious effects on the survival and function of leucocytes, and may contribute to the immunosuppression observed in these patients. However, Gln administration may restore the expression of HSP protecting tissues against injury (Singleton et al. 2005a, b, c, Morrison et al. 2006), improving survival in animals with abdominal sepsis (Singleton et al. 2005a, b). Recently, Singleton and Wischmeyer (2007), using knockout mice, demonstrated that the beneficial effects of glutamine on survival, lung injury, and the inflammatory response following cecal ligation and puncture surgery depended on the expression of HSP70.

The gene of HSP72 contains at least two regulatory elements that interact with heat shock transcription factors (HSFs) (Wu et al. 1986). The induction of HSP72 requires HSF-1 binding to the heat shock element (HSE) in the promoter region of the HSP70 gene (Pirkkala et al. 2001). Glutamine can initiate activation and lead to phosphorylation of HSF-1, yielding HSP expression and protecting cells against damage (Singleton et al. 2005a, Morrison et al. 2006). Recently, it was 
demonstrated that the molecular mechanism of Gln mediated HSP70 expression appears to be dependent on O-GlcNac pathway activation and subsequent O-glycosylation and phosphorylation of key transcription factors, HSF-1 and Sp1, required for HSP70 induction (Singleton and Wischmeyer 2008).

\section{MODULATION OF IMMUNE SYSTEM}

Glutamine is known to modulate immune cell function and production of cytokines. It may be mediated via attenuation of multiple pathways of inflammation, such as $\mathrm{NF}-\kappa \mathrm{B}$, kinases proteins, inhibition of increases in iNOS expression (Singleton et al. 2005a), attenuating the interactions between polymorphonuclear lymphocytes and endothelium, and decreasing neutrophil infiltration into tissues (Doruk et al. 2005, Yeh et al. 2005). Two pathways that can explain Gln's effects are: a) enhancement of MAPK phosphatase (MKP-1) expression, responsible for halting the production of pro-inflammatory cytokines, acting as an important negative regulator to inflammatory stimuli (Camps et al. 2000), b) inhibition of phosphorylation and degradation of $\mathrm{I} \kappa \mathrm{B}-\alpha$, an inhibitory protein that is bound to NF- $\kappa \mathrm{B}$, avoiding its translating to the nucleus (Zingarelli et al. 2003, Weiss et al. 2007) (Fig. 2).

Glutamine infusion can result in enhanced tissue glutathione levels, partly responsible in avoiding the activation of $\mathrm{NF}-\kappa \mathrm{B}$, and increase antioxidant capacity (Belmonte et al. 2007, Humbert et al. 2007). Whereas HSP70 protects cells against oxidative stress by the repair or removal of damage proteins, the second major protection factor of mammalian cells, the antioxidant glutathione, reacts directly with ROS in order to prevent oxidative damage. A significant correlation between reduced glutamine supply and diminished intracellular glutathione was observed in cultured peripheral blood mononuclear cells (Roth et al. 2002) and in critically patients (Wernerman et al. 1999). Doruk and colleagues (2005) showed reduced glutathione levels in the diaphragm of rats submitted to cecal ligation and puncture surgery, which was reversed with Gln administration.

Glutamine supplementation also promotes balanced Th1/Th2 response during sepsis, decreasing IL-6 secretion in non-hepatic organs, while reducing intra-lymphocyte IL-4 and enhancing IFN- $\alpha$ expressions (Yeh et al.
2005). O'Leary and colleagues (2007) showed in rats with abdominal sepsis that parenteral nutrition with glutamine recovered serum levels of IL- 6 and IL-10.

It is known that glutamine is an important fuel for lymphocytes and macrophages (Parry-Billings et al. 1990). Macrophages and neutrophils are involved in the early, non-specific host defense responses, and play an important role in the pathophysiology and/or protection against sepsis. In fact, this amino acid is required for the expression of lymphocyte cell surface markers, such as CD25, CD45RO, and CD17 (Roth et al. 2002). Additionally, septic rats pretreated with glutamine showed reduced neutrophil infiltration in diaphragm muscle, preventing biochemical and histopathological changes (Doruk et al. 2005). It has been demonstrated that Gln supplementation benefits the human leukocyte antigen-DR expression, essential molecule for antigen presentation, on monocytes in trauma and surgery patients (Boelens et al. 2002).

Another interesting question is the intestinal permeability. As glutamine is an important fuel for the enterocyte, intestinal consumption is important for maintaining the integrity of the intestinal barrier with subsequent prevention of bacterial translocation and, through stimulation of the gut-associated immune system, prevention of gut barrier atrophy. It is proposed that a derangement of the gut mucosal barrier function, which occurs during critical illnesses, results in an amplification of the general inflammatory response predisposing patients to multiple organ failure (Ziegler et al. 1988, van Der Hulst et al. 1998). The intestinal mucosa provides a barrier between bacteria and bacterial products in the intestinal lumen and body's circulation and organs. Prophylactic treatment with glutamine may minimize changes in intestinal permeability and bacteria translocation caused by endotoxemia in rats receiving total parenteral nutrition (Ding and Li 2003).

In summary, there is evidence that glutamine-starving cells show an increased susceptibility to cell stress and apoptosis, as well as a reduced responsiveness to pro-inflammatory stimuli (Fleshner et al. 2004, Ropeleski et al. 2005, Eliasen et al. 2006). The maintenance of plasma glutamine levels is essential for cells energy status, as well as for their functions and inflammatory response. 
A



B

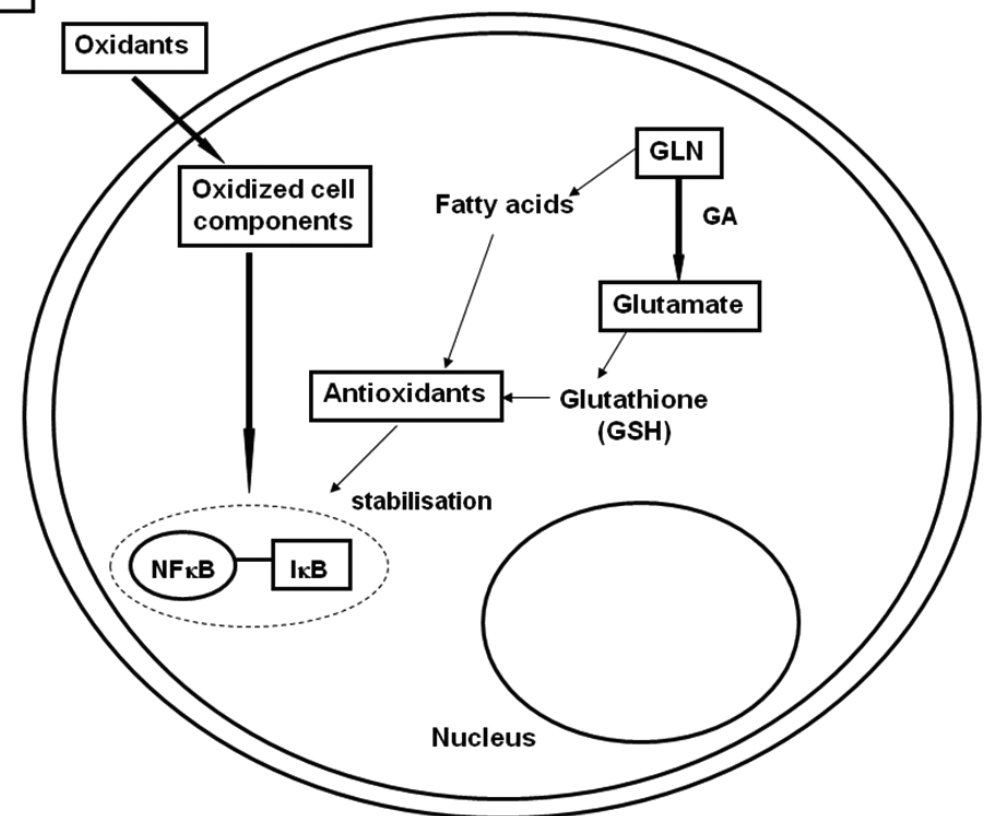

Fig. 2 - Nuclear factor (NF) $\kappa$ B activation pathway. Panel A: NF- $\kappa$ B is sequestered in the cytoplasm by its interaction with a member of the inhibitory kappa B ( $\mathrm{I} \kappa \mathrm{B})$ family. After an injurious stimuli, I $\kappa \mathrm{B}-\alpha$ is phosphorylated and degraded. Thus, NF- $\kappa \mathrm{B}$ is transported to the cell nucleus where it binds to DNA in the promoter regions of the target genes, transcripting many proinflammatory molecules that are responsible to the generation of inflammatory cascade during critical illnesses. Panel B: glutamine (Gln) may inhibit IKB- $\alpha$ phosphorylation and degradation in cytosolic tissue, avoiding the expression of many pro-inflammatory products. GA: glutaminase enzyme. 


\section{APOPTOSIS}

Apoptosis can be induced by a range of environmental, physical or chemical stress. Studies have established that the survival-promoting effects of HSP70 can be partly attributed to the suppression of apoptosis (Huang et al. 2001). The reduced HSP70 expression in glutaminestarving cells, together with their impaired antioxidant capacity, is thus likely to make them more sensitive to the induction of apoptosis.

Evidence showed that cells in the presence of glutamine are not sensitive to Fas ligand (Ko et al. 2001). JNK/SAPK pathway is involved in the apoptosis process increased by Fas stimulation. JNK/SAPK induced by Fas ligand is mediated by ASK1 (a critical protein kinase in apoptosis), which is activated after Fas ligand treatment only in the absence of Gln. Thus, Gln may suppress apoptosis signal-regulating kinase (ASK-1) and JNK/SAPK activation by Fas ligand (Ko et al. 2001). Furthermore, L-glutamine potentiation of HSP72 is associated with increased gut epithelial resistance to apoptotic injury, and reduced HSP72 may be associated with increased caspase activity in glutamine-deficient (Ropeleski et al. 2005). In fact, Gln induces autophagy under stressed conditions, and prevents apoptosis under heat stress through its regulation of the mTOR and $\mathrm{p} 38 \mathrm{MAP}$ kinase pathways (Sakiyama et al. 2009).

Glutathione (GSH) metabolism is also closely related to apoptotic processes of immune cells (Chang et al. 1999). The increase of intracellular GSH is sufficient to reduce Fas-triggered increase in apoptotic cells. An overexpression of Bcl-2, an anti-apoptotic protein, causes redistribution of glutathione to the nucleus, thereby altering nuclear redox and blocking caspase activity (Chang et al. 2002).

\section{GLUTAMINE AND THE DEVELOPMENT OF ACUTE LUNG INJURY/ACUTE RESPIRATORY DISTRESS SYNDROME}

Critically ill patients are at high risk of glutamine depletion (Planas et al. 1993) and subsequent complications, such as the developing of acute lung injury/acute respiratory distress syndrome (ARDS). Therapeutic interventions to improve outcomes from ALI/ARDS have met with limited success (Phua et al. 2009).

There are many experimental studies investigating the effects and the mechanisms responsible for glutamine's beneficial effects in ALI (Singleton et al. 2005a, b, c, Morrison et al. 2006, Singleton and Wischmeyer 2007). However, in these studies, glutamine was administered before (Ding and Li 2003, Doruk et al. 2005) or few hours (Singleton et al. 2005a, b) after the induction of lung injury. In this context, Gln could prevent neutrophil recruitment and infiltration (Yeh et al. 2005, Peng et al. 2006), protect the alveolar barrier (Singleton et al. 2005b), and attenuate inflammatory lung injury, leading to survival improvement (Singleton et al. 2005b). The mechanisms underlying the majority of these findings may be related to Gln's ability to induce heat shock protein (HSP) expression, which is known to enhance cell survival in the face of injury and attenuate the systemic inflammatory response (Singleton and Wischmeyer 2007), besides attenuating NF- $\kappa$ B pathway (Doruk et al. 2005, Yeh et al. 2005), buffering oxidative stress via glutathione generation (Oba et al. 2004), protecting gut barrier, and providing substrate for the appropriate division of immune cells (Oba et al. 2004)

Related to clinical trials, the studies have not investigated the development of ALI/ARDS as an end-point.

\section{CLINICAL STUDIES}

Evidence shows that nutritional support improves clinical outcomes in critical illnesses (Ziegler et al. 2005, Déchelotte et al. 2006, Juange et al. 2007). In this context, the concept of immunonutrition emerges: some nutrients are given in supranormal amounts to achieve a "pharmacological" effect (Déchelotte et al. 2006). Many nutrients are potentially considered immunonutrients, such as $\omega-3$ fatty acids, nucleotides, arginine, and glutamine.

In the early stage of acute critical illnesses, there is a low rate of adequate nutrition, including the development of malnutrition in pre and postoperative patients, and acute protein/energy malnutrition in children (Lewis et al. 2006). In this line, amino acids metabolism is characterized by low concentrations of muscle glutamine and high levels of the branched chain amino acids, indicating an inhibited intracellular glutamine formation in muscle tissue (Roth et al. 1982). The intracellular glutamine depletion in muscles occurs very early during ICU stay, and it seems to be constant over time (Gamrin et al. 1996). 
The same is also true for the free glutamine export from muscle, which suffers no alteration over time (Vesali et al. 2002). Furthermore, critically ill patients present plasma glutamine depletion, which is an independent factor additional to the APACHE II score for mortality prediction in ICU patients at admission (Oudemans-van Straaten et al. 2001).

Therefore, if a conditional deficiency occurs, critically ill patients should obtain some benefit with its exogenous replacement (Roth et al. 1982, Planas et al. 1993, Oudemans-van Straaten et al. 2001, Oehler et al. 2002). In fact, studies have demonstrated that Gln supplemented nutrition reduced the clinical complications of these patients (Wischmeyer et al. 2001, Ziegler et al. 2005, Déchelotte et al. 2006, Tang et al. 2007).

The option of Gln delivery via enteral or parenteral route is a subject of ongoing debate. The recent ICU guidelines have been consistent with their recommendations concerning the supplementation of Gln in parenteral nutrition (Heyland et al. 2003, Kreymann 2006). One study performed on patients with burns (Wischmeyer et al. 2001) reported reduced infections complication with the use of parenteral glutamine independent of the nutrition administration method. Total parenteral nutrition supplemented with alanil-glutamine dipeptide in ICU patients was associated with a reduced rate of infection, including the incidence of pneumonia, but it did not improve survival (Déchelotte et al. 2006). Surgical patients treated with parenteral nutrition containing alanil-glutamine dipeptide demonstrated reduced infectious morbidity rate (Estívariz et al. 2008, FuentesOrozco et al. 2008), as well as a significantly higher serum HSP70 level (Ziegler et al. 2005), which is correlated with a decrease in ICU length of stay. Patients after portal hypertension surgery receiving total parenteral nutrition supplemented with Gln presented an improvement in immune function and preservation of intestinal integrity (Tang et al. 2007) (Table I). These good results achieved with parenteral glutamine are due to adequate systemic delivery in the most severe patients.

However, clinical efficacy of glutamine supplementation was not demonstrated in some reports (Hall et al. 2003, Schulman et al. 2005, Juang et al. 2007), probably because of the heterogeneous patients populations studied, the use of different doses of glutamine, and the lack of a predictable physiologic end-point for glutamine supplementation previously identified in animals studies. Additionally, factors related to the clinical management need to be taken into account.

Although the guidelines about enteral/parenteral nutrition recommend the enteral route to delivery immunonutrients, so far there have not been sufficient data to support enteral glutamine supplementation in surgical or critically ill patients (Schulman et al. 2005, Juang et al. 2007). The addition of Gln to standard enteral feeds or to an immunomodulatory formula did not improve survival in intensive care unit patients (Hall et al. 2003, Schulman et al. 2005). In a retrospective case-control study, enteral glutamine supplementation was not associated with a change in the cumulative rate of infectious complications in burn intensive care patients (Juang et al. 2007). In a prospective study developed in a surgical trauma intensive care unit, there were no differences among the groups receiving enteral glutamine supplementation or standard feedings related to the acquisition of lung infections (Schulman et al. 2006) (Table I). One paper has demonstrated reduced mortality in adult burn patients given enteral glutamine supplements (Garrel et al. 2003). The controversial results may come from the patient population, as well as the amount and route of Gln administration (Table I). Indeed, burn patients may benefit the most from improved gut barrier function, including the competence of the gut immune system, since mortality rate is associated with systemic infection in this population.

The results of the meta-analysis of glutamine supplementation in young infants showed a modest treatment effect, with wide confidence intervals and the presence of heterogeneity across the studies. The Cochrane review of randomized controlled trials of glutamine supplementation for preterm infants concluded that there is no evidence that this procedure benefits or harms preterm infants (Tubman et al. 2005). Glutamine supplementation does not confer clinically significant benefits for infants with severe gastrointestinal disease (Grover et al. 2007). In meta-analysis of adult patients, the results are promising. In surgical patients, glutamine supplementation may be associated with a reduction in infectious complication rates and shorter hospital stay (Novak et al. 2002, Zheng et al. 2006, 2007), without any adverse 
TABLE I

Effect of enteral and parenteral glutamine in critical illnesses.

\begin{tabular}{|c|c|c|c|c|c|}
\hline Authors & Year & Study design & Patients & Glutamine dose & Results \\
\hline Wischmeyer et al. & 2001 & $\begin{array}{l}\text { Prospective, } \\
\text { double-blind, } \\
\text { randomized }\end{array}$ & $\begin{array}{l}\text { Burn intensive } \\
\text { care unit }(n=26)\end{array}$ & $\begin{array}{l}0.57 \mathrm{~g} / \mathrm{kg} \\
\text { parenteral }\end{array}$ & Reduced bacteremic episodes \\
\hline Garrel et al. & 2003 & $\begin{array}{l}\text { Double-blind, } \\
\text { randomized } \\
\text { clinical trial }\end{array}$ & Burn center $(n=41)$ & $\begin{array}{l}26 \mathrm{~g} / \mathrm{day} \\
\text { enteral }\end{array}$ & $\begin{array}{l}\text { Reduced blood infections and } \\
\text { decreased mortality }\end{array}$ \\
\hline Hall et al. & 2003 & $\begin{array}{l}\text { Prospective, } \\
\text { randomized }\end{array}$ & General ICU $(n=363)$ & $\begin{array}{l}20 \mathrm{~g} / 1 \\
\text { supplemented } \\
\text { enteral nutrition }\end{array}$ & $\begin{array}{l}\text { Did not reduce the incidence } \\
\text { of infectious }\end{array}$ \\
\hline Schulman et al. & 2005 & Prospective & $\begin{array}{l}\text { Surgical and } \\
\text { trauma }(\mathrm{n}=185)\end{array}$ & $\begin{array}{l}0.6 \mathrm{~g} / \mathrm{kg} \\
\text { enteral }\end{array}$ & $\begin{array}{l}\text { Did not improve survival and } \\
\text { the rate of infectious }\end{array}$ \\
\hline Ziegler et al. & 2005 & $\begin{array}{l}\text { Randomized, } \\
\text { controlled, } \\
\text { double-blind }\end{array}$ & Surgical unit $(\mathrm{n}=29)$ & $\begin{array}{l}0.50 \mathrm{~g} / \mathrm{kg} \\
\text { parenteral }\end{array}$ & Decreased ICU length of stay \\
\hline Déchelotte et al. & 2006 & $\begin{array}{l}\text { Prospective, } \\
\text { double-blind, } \\
\text { controlled, } \\
\text { randomized }\end{array}$ & $\begin{array}{l}\text { Multiple trauma, } \\
\text { complicated surgery, } \\
\text { pancreatitis }(n=114)\end{array}$ & $\begin{array}{l}0.50 \mathrm{~g} / \mathrm{kg} \\
\text { parenteral }\end{array}$ & Reduced rate of infectious \\
\hline Schulman et al. & 2006 & Prospective & $\begin{array}{l}\text { Surgical trauma } \\
\text { intensive care } \\
\text { unit }(n=185)\end{array}$ & $\begin{array}{l}0.60 \mathrm{~g} / \mathrm{kg} \\
\text { enteral }\end{array}$ & $\begin{array}{l}\text { Did not influence the acquisition } \\
\text { of characteristics of infectious }\end{array}$ \\
\hline Juang et al. & 2007 & $\begin{array}{l}\text { Retrospective } \\
\text { case-control }\end{array}$ & $\begin{array}{l}\text { Burn intensive } \\
\text { care unit }(n=32)\end{array}$ & $\begin{array}{l}0.52 \mathrm{~g} / \mathrm{kg} \\
\text { enteral }\end{array}$ & $\begin{array}{l}\text { Did not reduce infectious } \\
\text { complications }\end{array}$ \\
\hline Tang et al. & 2007 & $\begin{array}{l}\text { Prospective, } \\
\text { randomized } \\
\text { and controlled }\end{array}$ & $\begin{array}{l}\text { Portal hypertension } \\
\text { surgery }(n=42)\end{array}$ & $\begin{array}{l}0.30 \mathrm{~g} / \mathrm{kg} \\
\text { parenteral }\end{array}$ & $\begin{array}{l}\text { Improved immune function } \\
\text { and intestinal integrity }\end{array}$ \\
\hline Estívariz et al. & 2008 & $\begin{array}{l}\text { Double-blind, } \\
\text { randomized, } \\
\text { controlled }\end{array}$ & $\begin{array}{l}\text { Surgical } \\
\text { patients }(n=59)\end{array}$ & $\begin{array}{l}1.5 \mathrm{~g} / \mathrm{kg} / \mathrm{d} \\
\text { parenteral }\end{array}$ & $\begin{array}{l}\text { Reduced infectious in } \\
\text { SICU patients }\end{array}$ \\
\hline Fuentes-Orozco et al. & 2008 & $\begin{array}{l}\text { Prospective, } \\
\text { randomized }\end{array}$ & $\begin{array}{l}\text { Severe acute } \\
\text { pancreatitis }(n=44)\end{array}$ & $\begin{array}{l}0.50 \mathrm{~g} / \mathrm{kg} \\
\text { parenteral }\end{array}$ & $\begin{array}{l}\text { Decreased infectious } \\
\text { morbidity rate }\end{array}$ \\
\hline
\end{tabular}

effect on mortality. In critically ill patients, glutamine supplementation may be associated with a reduction in complication and mortality rates (Novak et al. 2002), but the greatest benefit was observed in patients receiving parenteral Gln.

The critical illness polyneuropathy (CIP) occurs mostly in patients who have systemic inflammatory response syndrome (SIRS), sepsis, or multiple organ dysfunction syndrome (MODS). CIP manifests especially with the weakness of the respiratory muscles, leading to problems in weaning from mechanical ventilation in the intensive care unit (Tennila et al. 2000). A prospective randomizing study in ICU patients using different doses of parenteral glutamine evaluated their effects on muscle (Tjäder et al. 2004) and showed that, in spite of all Gln doses being able to normalize plasma glutamine concentrations, Gln did not attenuate the depletion of muscle free glutamine frequently observed in ICU patients. Therefore, glutamine administration may not affect skeletal muscle turnover.

A multicenter randomized clinical trial (THE REDOXS STUDY) has been carried out to report the rationale and protocol for the evaluation of the effect of both supplemental glutamine and antioxidant strategies on mortality in mechanically ventilated, critically ill patients. This trial has been conducted in approximately twenty ICUs in Canada and the first results are expected in 2009 (Heyland et al. 2006). 


\section{CONCLUSIONS}

Several controlled studies suggest that glutamine supplementation has beneficial effects on the clinical outcome of critically ill patients. These results may be explained by the glutamine's influences on the inflammatory response, oxidative stress, apoptosis modulation, and the integrity of gut barrier. High-dose parenteral ( $>0.50 \mathrm{~g} / \mathrm{kg} /$ day) glutamine appears to present the greatest potential for benefit in critically ill patients. Additional studies should be performed to determine whether the outcomes are derived from the parenteral or enteral route, or if any specific group of patients could benefit from this therapy.

\section{ACKNOWLEDGMENTS}

We would like to express our gratitude to Mr. Andre Benedito da Silva and Mrs. Jaqueline Lima do Nascimento for their skillful technical assistance. This work is supported by Programa de Apoio a Núcleos de Excelência (PRONEX-FAPERJ), Conselho Nacional de Desenvolvimento Científico e Tecnológico (CNPq), Fundação Carlos Chagas Filho de Amparo à Pesquisa do Estado do Rio de Janeiro (FAPERJ), Instituto do Milênio Inovação e Desenvolvimento de Fármacos e Medicamentos (IM-INOFAR).

\section{RESUMO}

A glutamina (Gln) é uma importante fonte de energia e tem sido usada como substrato energético suplementar. Além disso, a Gln é um componente essencial para numerosas funções metabólicas tais como: homeostase ácido-base, gliconeogênese, transporte de nitrogênio e síntese de proteínas e ácidos nucléicos. Portanto, a glutamina desempenha um papel importante na homeostase celular e no metabolismo dos órgãos. Esse artigo objetiva rever os mecanismos de ação da glutamina na doença grave. Em pacientes criticamente enfermos, o aumento da mortalidade foi associado com uma diminuição de Gln plasmática. Durante o estresse catabólico, o consumo de Gln excede a oferta, e a quantidade de glutamina livre no plasma e músculo esquelético encontra-se reduzida. A dose e via de administração da Gln claramente influencia sua eficácia: alta dose por via parenteral parece ser mais benéfica do que uma dose baixa administrada por via enteral. Estudos experimentais relataram que Gln protege as células, tecidos, e todo o organismo do estresse através dos seguintes mecanismos: atenuação na ativação do fator nuclear (NF)- $\kappa \mathrm{B}$, balanço entre citocinas pró- e anti-inflamatórias, redução no acúmulo de neutrófilos, melhora na integridade intestinal e função imune celular, e aumento da expressão da proteína de choque térmico. Em conclusão, o uso de glutamina em altas doses e por via parenteral ( $>0,50 \mathrm{~g} / \mathrm{kg} / \mathrm{dia})$ demonstrou ser benéfica em pacientes criticamente enfermos, embora os mecanismos fisiopatológicos necessitam ser melhor elucidados.

Palavras-chave: proteína de choque término, apoptose, citocinas, glutamina.

\section{REFERENCES}

ABCouwer SF, Bode BP AND SoubA WW. 1995. Glucocorticoids regulate rat glutamine synthetase expression in a tissue-specific manner. J Surg Res 59: 59-65.

Andreasen AS, Pedersen-Skovsgaard T, MortenSen OH, Van Hall G, Moseley PL and Pedersen BK. 2009. The effect of glutamine infusion on the inflammatory response and HSP70 during human experimental endotoxemia. Crit Care 13: R7.

Asea A, Kraeft SK, Kurt-Jones EA, Stevenson MA, CHEN LB, Finberg RW, Koo GC ANd CALDERWOOd SK. 2000. HSP70 stimulates cytokine production through a CD14-dependant pathway, demonstrating its dual role as a chaperone and cytokine. Nat Med 6: 435-442.

BELMONTE L ET AL. 2007. Effects of glutamine supplementation on gut barrier, glutathione content and acute phase response in malnourished rats during inflammatory shock. World J Gastroenterol 13: 2833-2840.

Boelens PG, HoudiJk AP, Fonk JC, NiJVEldt RJ, FerWerda CC, Von Blomberg-VAN Der Flier BM, ThiJs LG, HAARMAN HJ, PUYANA JC AND VAN LEEUWEN PA. 2002. Glutamine-enriched enteral nutrition increases HLA-DR expression on monocytes of trauma patients. J Nutr 132: 2580-2586.

Boza JJ, Moennoz D, Bournot CE, Blum S, ZBinden I, Finot PA AND BALlevre O. 2000. Role of glutamine on the de novo purine nucleotide synthesis in Caco-2 cells. Eur J Nutr 39: 38-46.

Buttrose M, McKellar D And Welbourne TC. 1987. Gut-liver interaction in glutamine homeostasis: portal ammonia role in uptake and metabolism. Am J Physiol 252: E746-750.

CAmpisi J, LeEM TH AND Fleshner M. 2003. Stressinduced extracellular HSP72 is a functionally significant 
danger signal to the immune system. Cell Stress Chaperones 8: 272-286.

Camps M, Nichols A and Arkinstall S. 2000. Dual specificity phosphatases: a gene family for control of MAP kinase function. FASEB J 14: 6-16.

Chang WK, Yang KD and Shaio MF. 1999. Lymphocyte proliferation modulated by glutamine: involved in the endogenous redox reaction. Clin Exp Immunol 117: 482-488.

Chang WK, Yang KD, Chuang H, JAN JT And Shaio MF. 2002. Glutamine protects activated human T cells from apoptosis by up-regulating glutathione and Bcl-2 levels. Clin Immunol 104: 151-160.

Darmaun D, Matthews DE AND Bier DM. 1986. Glutamine and glutamate kinetics in humans. Am J Physiol 251: E117-126.

DÉChelotTe P ET AL. 2006. L-alanyl-L-glutamine dipeptide-supplemented total parenteral nutrition reduces infectious complications and glucose intolerance in critically ill patients: the French controlled, randomized, doubleblind, multicenter study. Crit Care Med 34: 598-604.

DING LA AND LI JS. 2003. Effects of glutamine on intestinal permeability and bacterial translocation in TPN-rats with endotoxemia. World J Gastroenterol 9: 1327-1332.

Doruk N, Buyukakilli B, Atici S, Cinel L, TAmer L, Avlan D, Bilgin E and Oral U. 2005. The effect of preventive use of alanyl-glutamine on diaphragm muscle function in cecal ligation and puncture-induced sepsis model. JPEN J Parenter Enteral Nutr 29: 36-43.

Elgadi KM, Labow BI, Abcouwer SF and Souba WW. 1998. Sepsis increases lung glutamine synthetase expression in the tumor-bearing host. J Surg Res 78: 1822.

Eliasen Mm, Brabec M, Gerner C, Pollheimer J, Auer H, Zellner M, Weingartmann G, Garo F, Roth E AND OEHLER R. 2006. Reduced stress tolerance of glutamine-deprived human monocytic cells is associated with selective down-regulation of HSP 70 by decreased mRNA stability. J Mol Med 84: 147-158.

ESTÍVARIZ CF ET AL. 2008. Efficacy of parenteral nutrition supplemented with glutamine dipeptide to decrease hospital infectious in critically ill surgical patients. JPEN J Parenter Enteral Nutr 32: 389-402.

Fleshner M, CAmpisi J, AMiri L And Diamond DM. 2004. Cat exposure induces both intra- and extra-cellular HSP72: the role of adrenal hormones. Psychoneuroendocrinology 29: 1142-1152.
Fuentes-Orozco C, Cervantes-Guevara G, MuciÑO-HERNÁNDEZ I, LÓPEZ-ORTEGA A, AMBRIZ-GONZÁLEZ G, GUTIÉRREZ-DE-LA-ROSA JL, GÓMEZ-HERRERA E, Hermosillo-SANdoval JM ANd GonzÁLEZ-OJEDA A. 2008. L-alanyl-L-glutamine-supplemented parenteral nutrition decreases infectious morbidity rate in patients with severe acute pancreatitis. JPEN J Parenter Enteral Nutr 32: 403-411.

GAMrin L, Essén P, Forsberg AM, HultMAN E AND WERNERMAN J. 1996. A descriptive study of skeletal muscle metabolism in critically ill patients: free amino acids, energy-rich phosphates, protein, nucleic acids, fat, water, and electrolytes. Crit Care Med 24: 575-583.

Ganter MT, Ware LB, Howard M, Roux J, GartLAnd B, Matthay MA, Fleshner M and Pittet JF. 2006. Extracellular heat shock protein 2 is a marker of the stress protein response in acute lung injury. Am J Physiol Lung Cell Mol Physiol 291: L354-361.

Garrel D, Patenaude J, Nedelec B, Samson L, Dorais J, Champoux J, D'Elia M AND BernieR J. 2003. Decreased mortality and infectious morbidity in adult burn patients given enteral glutamine supplements: a prospective, controlled, randomized clinical trial. Crit Care Med 31: 2444-2449.

Goeters C, Wenn A, Mertes N, Wempe C, Van AH, Stehle P And Bone HG. 2002. Parenteral L-alanylL-glutamine improves 6-month outcome in critically ill patients. Crit Care Med 30: 2032-2037.

Griffiths RD, Jones C AND PALMer TE. 1997. Sixmonth of critically ill patients given glutamine-supplemented parenteral nutrition. Nutrition 13: 295-302.

Grover Z, Tubman R AND McGuire W. 2007. Glutamine supplementation for young infants with severe gastrointestinal disease. Cochrane Database Syst Rev 24: CD005947.

Hall JC, Dobb G, Hall J, De Souza R, Brennan L AND MCCAULEY R. 2003. A prospective randomized trial of enteral glutamine in critical illness. Intensive Care Med 29: 1710-1716.

Heyland DK, Dhaliwal R, Drover JW, Gramlich L AND DodeK P. 2003. Canadian Critical Care Clinical Practice Guidelines Committee. Canadian clinical practice guidelines for nutrition support in mechanically ventilated, critically ill adult patients. JPEN J Parenter Enteral Nutr 27: 355-373.

Heyland DK, Dhaliwal R, Day AG, Muscedere J, Drover J, Suchner U AND CoOK D. 2006. Canadian 
Critical Care Trials Group. Reducing deaths due to oxidative stress (The REDOXS Study): Rationale and study design for a randomized trial of glutamine and antioxidant supplementation in critically-ill patients. Proc Nutr Soc 65: 250-263.

HuAng L, Mivechi NF AND Moskophidis D. 2001. Insights into regulation and function of the major stressinduced hsp70 molecular chaperone in vivo: analysis of mice with targeted gene disruption of the hsp70.1 or hsp70.3. Mol Cell Biol 21: 8575-8591.

Humbert B, Nguyen P, Martin L, Dumon H, ValLetTe G, Maugère P AND DARMAUn D. 2007. Effect of glutamine on glutathione kinetics in vivo in dogs. J Nutr Biochem 18: 10-16.

JuAng P, Fish DN, Jung R AND MACLAREN R. 2007. Enteral glutamine supplementation in critically ill patients with burn injuries: a retrospective case-control evaluation. Pharmacotherapy 27: 11-19.

KARINCh AM, PAN M, Lin CM, Strange R ANd Souba WW. 2001. Glutamine metabolism in sepsis and infection. J Nutr 131(Suppl 9): 2535S-2538S.

Ko YG, Kim EY, Kim T, PARK H, PARK HS, ChOI EJ AND KIM S. 2001. Glutamine-dependent antiapoptotic interaction of human glutaminyl-t RNA synthetase with apoptosis signal-regulating kinase 1. J Biol Chem 276: 6030-6036.

KREYMANN KG. 2006. German Society for Nutritional Medicine and European Society for Parenteral and Enteral Nutrition. ESPEN Guidelines on Enteral Nutrition: Intensive care. Clin Nutr 25: 210-223.

LABow BI, Abcouwer SF, Lin CM AND SoubA WW. 1998. Glutamine synthetase expression in the rat lung is regulated by protein stability. Am J Physiol 275: 18771886.

LABOW BI, SoubA WW AND ABCOUver SF. 1999. Glutamine synthetase expression in muscle is regulated by transcriptional and posttranscriptional mechanisms. Am J Physiol 276: 1136-1145.

Labow BI, Souba WW ANd AbCouWer SF. 2001. Mechanisms governing the expression of the enzymes of glutamine metabolism - Glutaminase and Glutaminase Synthetase. J Nutr 131: 2467S-2474S.

Lewis MI, Bodine SC, KAMAGar N, XU X, DA X AND FOURNIER M. 2006. Effect of severe short-term malnutrition on diaphragm muscle signal transduction pathways influencing protein turnover. J Appl Physiol 100: 17991806.
Mezzarobba V, Torrent A, Leydier I, Alles S, Brajon B, Mignon M, Attaix D and Meynial-Denis D. 2003. The role of adrenal hormones in the response of glutamine synthetase to fasting in adult and old rats. Clin Nutr 22: 569-575.

Morrison AL, Dinges M, Singleton KD, Odoms K, WONG HR AND WISCHMEYER PE. 2006. Glutamine's protection against cellular injury is dependent on heat shock factor-1. Am J Physiol Cell Physiol 290: C16251632.

Newsholme P, Curi R, Gordon S And Newsholme EA. 1986. Metabolism of glucose, glutamine, long-chain fatty acids and ketone bodies by murine macrophages. Biochem J 239: 121-125.

Novak F, Heyland DK, Avenell A, Drover JW AND SU X. 2002. Glutamine supplementation in serious illness: a systematic review of the evidence. Crit Care Med 30: 2022-2029.

OBA M, BALDWIN RL AND BEQUetTE BJ. 2004. Oxidation of glucose, glutamate, and glutamine by isolated ovine enterocytes in vitro is decreased by the presence of other metabolic fuels. J Anim Sci 82: 479-486.

Oehler R, Pusch E, Zellner M, Dungel P, HergovICS N, Homoncik M, Eliasen MM, BRABEC M AND RoTH E. 2001. Cell type-specific variations in the induction of hsp70 in human leukocytes by feverlike whole body hyperthermia. Cell Stress and Chaperones 6: 306-315.

Oehler R, Pusch E, Dungel P, Zellner M, Eliasen MM, BRABEC M AND Roth E. 2002. Glutamine depletion impairs cellular stress response in human leucocytes. Br J Nutr 87(Suppl): S17-21.

O'Leary MJ, Xue A, Scarlett CJ, Sevette A, Kee AJ AND SMIth RC. 2007. Parenteral versus enteral nutrition: effect on serum cytokines and the hepatic expression of mRNA of suppressor of cytokine signaling proteins, insulin-like growth factor-1 and the growth hormone receptor in rodent sepsis. Crit Care 11: R79.

Oudemans-van StraAten HM, Bosman RJ, Treskes M, VAn Der Spoel HJ AND Zandstra DF. 2001. Plasma depletion and patient outcome in acute ICU admissions. Intensive Care Med 27: 84-90.

Parry-Billings M, Evans J, CAlder PC AND NewSHOLME EA. 1990. Does glutamine contribute to immunosuppression after major burns? Lancet 336: 523 525.

Peng ZY, Hamiel CR, BAnerJee A, Wischmeyer Pe, FRIESE RS AND WISCHMEYER P. 2006. Glutamine attenuation of cell death and inducible nitric oxide synthase 
expression following inflammatory cytokine-induced injury is dependent on heat shock factor-1 expression. JPEN J Parenter Enteral Nutr 30: 400-406.

PhUA J ET AL. 2009. Has mortality from acute respiratory distress syndrome decreased over time? A systematic review. Am J Respir Crit Care Med 179: 220-227.

Pirkkala L, Nykanen P And Sistonen L. 2001. Roles of the heat shock transcription factors in regulation of the heat shock response and beyond. FASEB J 15: 11181131.

Planas M, Schwartz S, Arbos MA and Farriol M. 1993. Plasma glutamine levels in septic patients. JPEN J Parenter Enteral Nutr 17: 299-300.

Ropeleski MJ, Riehm J, BAer KA, Musch MW AND CHANG EB. 2005. Anti-apoptotic effects of L-Glutamine-mediated transcriptional modulation of the heat shock protein 72 during heat shock. Gastroenterology 129 : 170-184.

Roth E, Funovics J, Muhlbacher F, Schemper M, Mauritz W AND Fritsch A. 1982. Metabolic disorders in severe abdominal sepsis: Glutamine deficiency in skeletal muscle. Clin Nutr 1: 25-41.

Roth E, Oehler R, Manhart N, Exner R, Wessner B, Strasser E And Spittler A. 2002. Regulative potential of glutamine-relation to glutathione metabolism. Nutrition 18: 217-221.

SAKiyama T, Musch MW, Ropeleski MJ, Tsubouchi H AND CHANG EB. 2009. Glutamine increases autophagy under Basal and stressed conditions in intestinal epithelial cells. Gastroenterology 136: 924-932.

Schulman AS ET AL. 2005. Does the addition of glutamine to enteral feeds affect patient mortality? Crit Care Med 33: 2501-2506.

Schulman AS ET AL. 2006. Does enteral glutamine supplementation decrease infectious morbidity? Surg Infect (Larchmt) 7: 29-35.

Singleton KD AND WischmeYER PE. 2007. Glutamine's protection against sepsis and lung injury is dependent on heat shock protein 70 expression. Am J Physiol Regul Integr Comp Physiol 292: R1839-1845.

Singleton KD AND WischmeYeR PE. 2008. Glutamine induces heat shock protein expression via O-glycosylation and phosphorylation of HSF-1 and Sp1. JPEN J Parenter Enteral Nutr 32: 371-376.

Singleton KD, Beckey VE AND Wischmeyer PE. 2005a. Glutamine prevents activation of NF- $\kappa$ B and stress kinase pathways, attenuates inflammatory cytokine release, and prevents acute respiratory distress syndrome (ARDS) following sepsis. Shock 24: 583-589.

Singleton KD, Serkova N, Beckey VE And WischMEYER PE. 2005b. Glutamine attenuates lung injury and improves survival after sepsis: Role of enhanced heat shock protein expression. Crit Care Med 33: 1206-1213.

Singleton KD, Serkova N, Banerjee A, Meng $\mathrm{X}$, Gamboni-Robertson F And Wischmeyer PE. 2005c. Glutamine attenuates endotoxin-induced lung metabolic dysfunction: potential role of enhanced heat shock protein 70. Nutrition 21: 214-223.

TANG ZF, Ling YB, Lin N, HAO Z AND XU RY. 2007. Glutamine recombinant human growth hormone protects intestinal barrier function following portal hypertension surgery. World J Gastroenterol 13: 2223-2228.

Tennila A, Salmi T, Pettila V, Roine RO, Varpula T AND TAKKUNEN O. 2000. Early signs of critical illness polyneuropathy in ICU patients with systemic inflammatory response syndrome or sepsis. Intensive Care Med 26: 1360-1363.

TJÄDER I, RoOyACKERS O, Forsberg AM, VESAli RF, GARLiCK PJ AND Wernerman J. 2004. Effects on skeletal muscle of intravenous glutamine supplementation to ICU patients. Intensive Care Med 30: 266-275.

Tubman TR, Thompson SW And McGuire W. 2005. Glutamine supplementation to prevent morbidity and mortality in preterm infants. Cochrane Database Syst Rev 25: CD001457.

VAn Der Hulst RR, Von Meyenfeldt MF, VAn Kreel BK, Thunnissen FB, BRummer R, AREnds JW AND SOETERS PB. 1998. Gut permeability, intestinal morphology, and nutritional depletion. Nutrition 14: 1-6.

Vesali RF, Klaude M, Rooyackers Oe, TJader I, BARLE H AND WERNERMAN J. 2002. Longitudinal pattern of glutamine/glutamate balance across the leg in longstay intensive care unit patients. Clin Nutr 21: 505-514.

Weiss YG, Bromberg Z, RAJ N, RAPHAEL J, GoloubiNOFF P, BEN-NERIAH Y AND DEUSTCHMAN CS. 2007. Enhanced heat shock protein 70 expression alters proteasomal degradation of IkappaB kinase in experimental acute respiratory distress syndrome. Crit Care Med 35: 21282138.

WERnERMAN J, LuO JL AND HAMmarqVist F. 1999. Glutathione status in critically-ill patients: possibility of modulation by antioxidants. Proc Nutr Soc 58: 677-680. 
Wischmeyer PE, Lynch J, Liedel J, Wolfson R, Riehm J, Gottlieb L And Kahana M. 2001. Glutamine administration reduces Gram-negative bacteremia in severely burned patients: A prospective, randomized, double-blind trial versus isonitrogenous control. Crit Care Med 29: 2075-2080.

Wright BH, CORTON JM, El-Nahas AM, Wood RF AND Pockley AG. 2000. Elevated levels of circulanting heat shock protein 70 (HSP70) in peripheral and renal vascular disease. Heart Vessels 15: 18-22.

Wu BJ, Kingston RE And Morimoto RI. 1986. Human HSP70 promoter contains at least two distinct regulatory domains. Proc Natl Acad Sci USA 83: 629-633.

Yeh CL, Hsu CS, Yeh SL AND Chen WJ. 2005. Dietary glutamine supplementation modulates Th1/Th2 cytokine and interleukin- 6 expressions in septic mice. Cytokine 31: 329-334.

ZHENG YM, Li F, ZHANG MM AND WU XT. 2006. Glutamine dipeptide for parenteral nutrition in abdominal surgery: a meta-analysis of randomized controlled trials. World J Gastroenterol 12: 7537-7541.
Zheng YM, Li F, Qi B, LuO B, Sun H, LiU S AND Wu X. 2007. Application of perioperative immunonutrition for gastrointestinal surgery: a meta-analysis of randomized controlled trials. Asia Pac J Clin Nutr 16 Suppl 1: 253257.

Ziegler TR, SMith RJ, O'DWyer ST, Demling RH AND WILMORE DW. 1988. Increased intestinal permeability associated with infection in burn patients. Arch Surg 123: 1313-1319.

Ziegler TR, OGden LG, Singleton KD, LuO M, FERNANDEZ-ESTIVARIZ C, GRIFFITH DP, GALLOWAY JR AND WischmeYer PE. 2005. Parenteral glutamine increases serum heat shock protein 70 in critically ill patients. Intensive Care Med 31: 1079-1086.

Zingarelli B, Sheehan M And Wong HR. 2003. Nuclear factor-kappa $\mathrm{B}$ as a therapeutic target in critical care medicine. Crit Care Med 31: S105-S111. 